[Chem. Pharm. Bull.

$[35(6) 2327-2333(1987)]$

\title{
Synthesis of Head Activator (HA)-Related Peptides and Development of HA-Radioimmunoassay
}

\author{
NaOki SaKura, ${ }^{*}$ Miwako Nishijima, Yoshiki Uchida, \\ Tetsuhiro Tani, and Tadashi Hashimoto
}

School of Pharmacy, Hokuriku University, Kanagawa-machi, Kanazawa 920-11, Japan

(Received November 20, 1986)

\begin{abstract}
Synthesis of peptides related to hydra head activator (HA; pGlu-Pro-Pro-Gly-Gly-Ser-LysVal-Ile-Leu-Phe-OH) was performed by the solution method. The analogs synthesized were $\mathrm{Tyr}^{11}$-HA, des-Phe ${ }^{11}-\mathrm{HA}, \mathrm{Arg}^{1}-\mathrm{HA}$ and $\mathrm{Phe}^{5}$-HA. Antisera were prepared by immunizing three rabbits with the synthetic HA. Two anti-HA-antisera with sufficient titer were obtained. An HAradioimmunoassay system, developed by using an antiserum (ASH-04) and ${ }^{125}{ }^{-}-\mathrm{Tyr}^{11}-\mathrm{HA}$ as a tracer, was found to be sensitive and specific to HA.
\end{abstract}

Keywords - head activator; synthesis; antibody preparation; ${ }^{125} \mathrm{I}-\mathrm{Tyr}^{11}$-head activator; radioimmunoassay; specificity; droplet counter current chromatography; HPLC

The hydra head activator (HA) is an undecapeptide isolated from the fresh water hydra and the sea anemone, and sequenced as pGlu-Pro-Pro-Gly-Gly-Ser-Lys-Val-Ile-Leu-Phe$\mathrm{OH}^{1)}(\mathrm{I})$. The peptide is a growth hormone-like factor in hydra stimulating head specific growth or bud formation, together with other morphogenous factors. ${ }^{2)}$ A peptide with complete sequence homology occurs not only in the coelenterates but also in mammals-human, bovine and rat hypothalami, and intestine. ${ }^{3)}$ Except for the induction of amylase release from rat pancreas in vitro but not in vivo, and a weak stimulatory effect on smooth muscle, ${ }^{4)}$ no biological activity or physiological function of HA has been reported in mammals.

In the present paper we describe: a) the synthesis of four HA-related peptides (Fig. 1), and b) the development of an HA-radioimmunoassay (RIA).

Synthesis of HA-related peptides was carried out by a conventional solution method. The protected peptides prepared as units for successive azide fragment condensation to build up the peptide backbones were as follow; Z-pGlu-Pro-Pro-Gly-NHNHBoc (VI), Z-Arg $\left(\mathrm{NO}_{2}\right)-$ Pro-Pro-Gly-NHNHBoc, ${ }^{5)}$ Boc-Gly-Ser- $\mathrm{N}_{2} \mathrm{H}_{3},{ }^{6}$ ) Boc-Phe-Ser- $\mathrm{N}_{2} \mathrm{H}_{3},{ }^{7)}$ Boc-Lys(Z)-ValIle-Leu-Tyr-OH (VII), Boc-Lys(Z)-Val-Ile-Leu-OH (VIII) and Boc-Lys(Z)-Val-IleLeu-Phe-OH (IX). In Fig. 2, the synthetic route is shown for an analog, $\mathrm{Tyr}^{11}-\mathrm{HA}$ (II), which

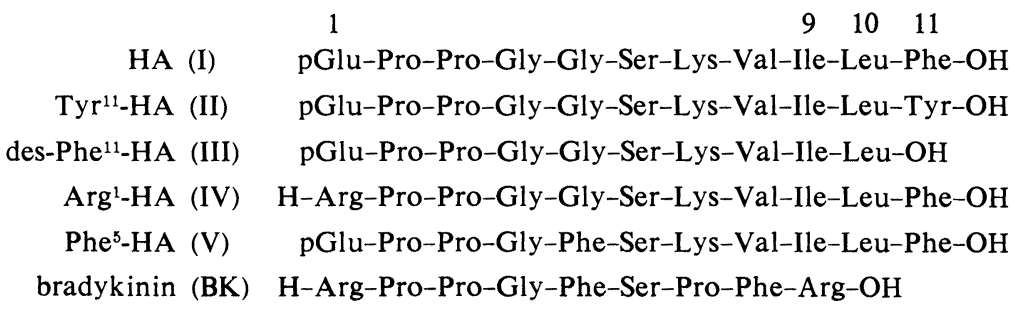

Fig. 1. Head Activator (HA) and Related Peptides 


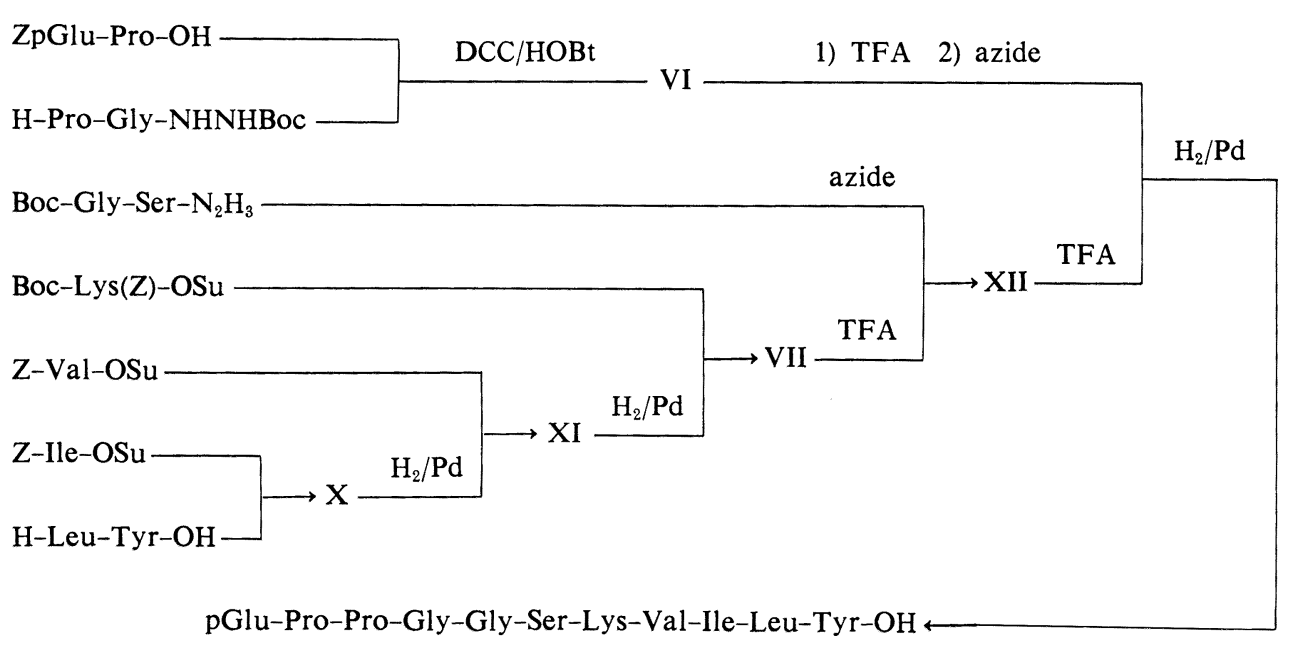

(II)

Fig. 2. Synthesis of $\mathrm{Tyr}^{11}-\mathrm{HA}$ (II)

was designed as a labelled antigen preparation with minimum structural modification (replacing C-terminal Phe by Tyr). The C-terminal protected pentapeptide (VII) was prepared in a stepwise fashion by the active ester method. The starting material, $\mathrm{H}-\mathrm{Leu}-\mathrm{Tyr}-\mathrm{OH}^{8)}$ was coupled with Z-Ile-OSu to yield Z-Ile-Leu-Tyr-OH (X). Debenzyloxycarbonylation of X by catalytic hydrogenation followed by coupling with Z-Val-OSu gave Z-Val-Ile-Leu-Tyr-OH (XI), which was deprotected by the same procedure. Acylation of the resulting tetrapeptide with the active ester of Boc-Lys(Z)-OH gave VII. Removal of the $\mathrm{N}^{\alpha}-\mathrm{Boc}$ group of VII was carried out by treatment with trifluoroacetic acid (TFA) at $15^{\circ} \mathrm{C}$ for $45 \mathrm{~min}$ to suppress $\mathrm{N}^{\varepsilon}-\mathrm{Z}$ cleavage of Lys. ${ }^{9)}$ The resulting pentapeptide $\mathrm{H}-\mathrm{Lys}(\mathrm{Z})-\mathrm{Val}-\mathrm{Ile}-\mathrm{Leu}-\mathrm{Tyr}-\mathrm{OH} \cdot \mathrm{TFA}$ (VII') was condensed with Boc-Gly-Ser- $\mathrm{N}_{2} \mathrm{H}_{3}{ }^{6)}$ by the azide method ${ }^{10)}$ and the protected heptapeptide Boc-Gly-Ser-Lys(Z)-Val-Ile-Leu-Tyr-OH (XII) obtained was further subjected to detert-butyloxycarbonylation under the same conditions as described above.

The N-terminal tetrapeptide (VI) was prepared by the reaction between $\mathrm{Z}$-pGlu-Pro$\mathrm{OH}^{11)}$ and $\mathrm{H}-\mathrm{Pro}-\mathrm{Gly}-\mathrm{NHNHBoc}{ }^{5)}$ with the dicyclohexylcarbodiimide (DCC)-Nhydroxybenzotriazole (HOBt) procedure. ${ }^{12)}$ The final coupling of $\mathrm{Z}-\mathrm{pGlu}-\mathrm{Pro}-\mathrm{Pro}-\mathrm{Gly}-\mathrm{N}_{3}$ derived from VI with $\mathrm{H}-\mathrm{Gly}-\mathrm{Ser}-\mathrm{Lys}(\mathrm{Z})-\mathrm{Val}-\mathrm{Ile}-\mathrm{Leu}-\mathrm{Tyr}-\mathrm{OH}\left(\mathrm{XII}^{\prime}\right)$ yielded the protected undecapeptide Z-pGlu-Pro-Pro-Gly-Gly-Ser-Lys(Z)-Val-Ile-Leu-Tyr-OH, which was hydrogenated to give crude II. Purification of peptide II was performed by droplet counter current chromatography (DCCC), ${ }^{13)}$ with a solvent system of $n$-butanol-acetic acid-water $(4: 1: 5)$. The desired peptide emerged after the solvent front of the lower phase used as the mobile phase. A highly purified product was obtained after gel filtration on Sephadex G-25 using $2 \mathrm{M}$ acetic acid as the solvent. The homogeneity of this peptide was proved by thin layer chromatography (TLC), high performance liquid chromatography (HPLC), elemental analysis and amino acid analysis of the acid hydrolysate.

The other three HA analogs, des-Phe ${ }^{11}$-HA (III), $\mathrm{Arg}^{1}$-HA (IV) and $\mathrm{Phe}^{5}$-HA (V), were synthesized in the same manner as described above, starting from VIII or IX as the C-terminal fragment. HA itself was also prepared and extensively purified by DCCC employing two different solvent systems. The homogeneity of the synthetic peptides was proved by the same means as used for II. The synthetic HA prepared in this study had the same biological activity as the native peptide. It also cross-reacted with the HA-RIA system developed by Bodenmüller et al. ${ }^{14)}$ Cross-reactivity and homogeneity data are summarized in Table I. 
TABlE I. Characterization of Synthetic Peptides

\begin{tabular}{ccccc}
\hline \hline Peptide & $R f^{1}$ & $R f^{2}$ & $\begin{array}{c}\text { Retention time } \\
(\mathrm{min})\end{array}$ & $\begin{array}{c}\text { Cross-reactivity } \\
(\%)\end{array}$ \\
\hline I & 0.17 & 0.59 & 12.35 & 100 \\
II & 0.13 & 0.56 & 8.71 & 100 \\
III & 0.11 & 0.48 & 7.43 & 1 \\
IV & 0.02 & 0.53 & 9.53 & 0.03 \\
V & 0.25 & 0.64 & 16.06 & 0.3 \\
\hline
\end{tabular}

a) Conditions of analytical HPLC: column, $\mu$-Bondapak $\mathrm{C}_{18}(4 \times 300 \mathrm{~mm})$; flow rate, $1 \mathrm{ml} / \mathrm{min}$; detection, $210 \mathrm{~nm}$; eluent system, linear gradient from $25 \%$ to $45 \% \mathrm{CH}_{3} \mathrm{CN}$ (15 min) in $20 \mathrm{~mm}$ phosphate buffer ( $\mathrm{pH} 3.0)$.

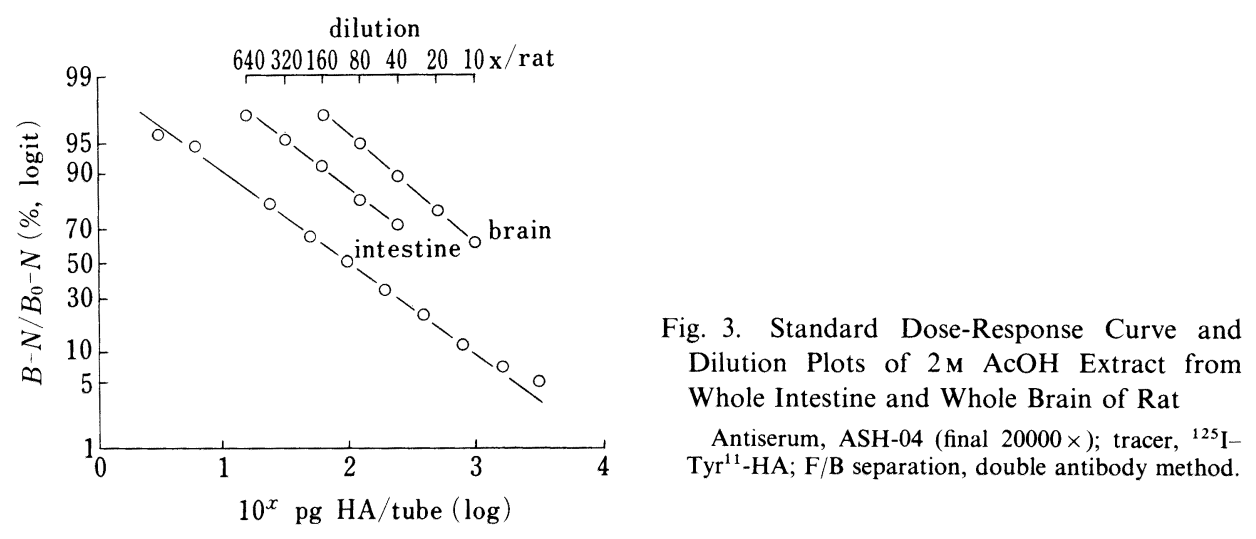

To obtain a specific antiserum, we used HA-ascaris protein conjugates, ${ }^{15)}$ prepared by using glutaraldehyde. Immunization of three rabbits with the conjugate gave antibodies with sufficient titer. ${ }^{125} \mathrm{I}-\mathrm{Tyr}^{11}$-HA was prepared by the Iodogen method. ${ }^{16)}$ Purified labelled antigen was separated from the unlabelled antigen and other compounds by reversed-phase HPLC.

The specificity of these antisera was examined, and the antiserum ASH-04 was found to be more specific in binding to the undecapeptide HA than the others. In the HA-RIA using ASH-04 at a final dilution of 20000 fold, the cross-reactivities of the three HA analogs and bradykinin (BK) were examined. The dose-response curves of III, IV and V, which resemble $\mathrm{BK}$, revealed that the minor change of the HA molecule resulted in a drastic decrease of the binding activity with the antisera (Table I). The Gly ${ }^{5}$ residue seemed to be important for binding with the antibody ASH-04, while BK did not cross-react at all. These results clearly indicate that the assay system is specific for the undecapeptide. In HA-RIA by the double antibody method, less than $10 \mathrm{pg}$ of HA per tube was detectable; $2 \mathrm{~N}$ acetic acid extracts of rat whole intestine and whole brain displaced the tracer in a manner parallel to that of synthetic HA (Fig. 3). The content of immunoreactive HA, however, was found to be extremely low. The results suggest that the RIA system established here could be useful for further immunological studies on the head activator.

\section{Experimental}

Melting points are uncorrected. Optical rotations were measured in a Nippon Bunkoh DIP-4 polarimeter. Amino acid analyses were performed with a Hitachi KLA-5 amino acid analyzer. HPLC was performed on a system 
composed of two model 510 pumps, a model U6K injector, a model 680 gradient controller, a model 481 LC spectrophotometer and a data module, model 730 (Waters). Radioactivity was counted with an Auto Well Gamma System, ARC-360 (Aloka). Acid hydrolysis of samples for amino acid analysis was conducted with twice-distilled $5.8 \mathrm{~N} \mathrm{HCl}$ at $110^{\circ} \mathrm{C}$ for $24 \mathrm{~h}$ and for $48 \mathrm{~h}$ in evacuated sealed tubes, and phenol was added thereto when the peptide contained tyrosine. Evaporation of solvents was carried out in vacuo below $45^{\circ} \mathrm{C}$ in a rotary evaporator. The solvent systems used for TLC on silica gel (Merck) were $n$ - $\mathrm{BuOH}-\mathrm{AcOH}-\mathrm{H}_{2} \mathrm{O}\left(4: 1: 5\right.$, the upper phase, $\left.R f^{1}\right)$ and $n$ - $\mathrm{BuOH}-$ pyridine- $\mathrm{AcOH}-\mathrm{H}_{2} \mathrm{O}\left(30: 20: 6: 24, R f^{2}\right)$.

Z-Ile-Leu-Tyr-OH (X) - Z-Ile-OSu $(2.21 \mathrm{~g}, 6.1 \mathrm{mmol})$ was allowed to react at room temperature with $\mathrm{H}-$ Leu-Tyr-OH ${ }^{8)}(1.38 \mathrm{~g}, 4.7 \mathrm{mmol})$ in dimethylformamide (DMF) $(15 \mathrm{ml})-\mathrm{H}_{2} \mathrm{O}(6 \mathrm{ml})$ containing triethylamine (TEA) $(1.32 \mathrm{ml}, 9.4 \mathrm{mmol})$ for $16 \mathrm{~h}$. After evaporation of the solvents, the residue in AcOEt was washed successively with $1 \mathrm{~N}$ $\mathrm{HCl}$ and saturated $\mathrm{NaCl}$ solution. The organic phase was dried over $\mathrm{Na}_{2} \mathrm{SO}_{4}$ and evaporated. The residue was triturated with ether-petr. ether and the solid was reprecipitated from the same solvents. Yield $2.47 \mathrm{~g}(96.9 \%) . \mathrm{mp}$ 123-125 ${ }^{\circ}$ C. $R f^{1} 0.85, R f^{2} 0.82$. [ $\left.\alpha\right]_{\mathrm{D}}^{21}-0.07^{\circ}(c=1.0, \mathrm{DMF})$. Anal. Calcd for $\mathrm{C}_{29} \mathrm{H}_{39} \mathrm{~N}_{3} \mathrm{O}_{7}: \mathrm{C}, 64.31 ; \mathrm{H}, 7.26 ; \mathrm{N}$, 7.76. Found: C, 63.92; H, 7.30; N, 7.57.

Z-Val-Ile-Leu-Tyr-OH (XI) - X (2.33 g, $4.3 \mathrm{mmol})$ was hydrogenated in $n$ - $\mathrm{BuOH}(40 \mathrm{ml})-\mathrm{MeOH}(40 \mathrm{ml})$ $10 \% \mathrm{AcOH}(80 \mathrm{ml})$ over $\mathrm{Pd}$-black for $20 \mathrm{~h}$. The catalyst was removed by filtration and the filtrate was concentrated to a small volume. The residue was precipitated from EtOH. Yield $1.75 \mathrm{~g}(87.0 \%) . R f^{1} 0.77, R f^{2} 0.80$. Z-Val-OSu $(1.42 \mathrm{~g}, 4.1 \mathrm{mmol})$ was coupled with $\mathrm{H}-\mathrm{Ile}-\mathrm{Leu}-\mathrm{Tyr}-\mathrm{OH}(1.59 \mathrm{~g}, 3.4 \mathrm{mmol})$ obtained above in $\mathrm{H}_{2} \mathrm{O}(6 \mathrm{ml})-$ dimethylsulfoxide (DMSO) ( $2 \mathrm{ml})$-DMF $(20 \mathrm{ml})$ containing TEA $(0.81 \mathrm{ml}, 5.8 \mathrm{mmol})$ at room temperature for $20 \mathrm{~h}$. The solvents were evaporated off and the residue was triturated with $10 \% \mathrm{AcOH}$. The solid was reprecipitated from $\mathrm{MeOH}$-ether. Yield $1.73 \mathrm{~g}\left(79.4^{\circ}\right) . \mathrm{mp} 232-233^{\circ} \mathrm{C} . R f^{1} 0.87, R f^{2} 0.75 .[\alpha]_{\mathrm{D}}^{21}-2.6^{\circ}(c=1.0$, DMF $)$. Anal. Calcd for $\mathrm{C}_{34} \mathrm{H}_{48} \mathrm{~N}_{4} \mathrm{O}_{8}$ : C, 63.73; H, 7.55; N, 8.74. Found: C, 63.37; H, 7.57; N, 8.46.

Boc-Lys(Z)-Val-Ile-Leu-Tyr-OH (VII) XI $(1.60 \mathrm{~g}, 2.5 \mathrm{mmol})$ was hydrogenated in $n$-BuOH $(15 \mathrm{ml})-$ $\mathrm{MeOH}(60 \mathrm{ml})-50 \% \mathrm{AcOH}(30 \mathrm{ml})$ in the same manner as described for XI. Yield $1.26 \mathrm{~g}(88.7 \%) \cdot R f^{1} 0.75, R f^{2} 0.80$. Boc-Lys(Z)-OSu [prepared from Boc-Lys(Z)-OH $(0.989 \mathrm{~g}, 2.6 \mathrm{mmol}), N$-hydroxysuccinimide $(\mathrm{HOSu})(0.314 \mathrm{~g}$, $2.73 \mathrm{mmol})$, and DCC $(0.563 \mathrm{~g}, 2.73 \mathrm{mmol})$ in DMF $(1 \mathrm{ml})-\mathrm{THF}(10 \mathrm{ml})$ as usual] was coupled with the tetrapeptide obtained above in $\mathrm{H}_{2} \mathrm{O}(8 \mathrm{ml})$-DMSO $(15 \mathrm{ml})$-DMF $(40 \mathrm{ml})$ at room temperature for $20 \mathrm{~h}$. The mixture was treated in the same manner as described for XI and reprecipitated from AcOEt-ether. Yield $0.58 \mathrm{~g}(39.1 \%)$. mp $275-277^{\circ} \mathrm{C}$ (dec.). $R f^{1} 0.85, R f^{2} 0.81$. $[\alpha]_{\mathrm{D}}^{21}-11.1^{\circ}\left(c=0.7\right.$, DMF). Anal. Calcd for $\mathrm{C}_{45} \mathrm{H}_{68} \mathrm{~N}_{6} \mathrm{O}_{11} \cdot 3 / 2 \mathrm{H}_{2} \mathrm{O}: \mathrm{C}, 60.32 ; \mathrm{H}, 7.99 ; \mathrm{N}$, 9.38. Found: C, $60.41 ; \mathrm{H}, 7.85 ; \mathrm{N}, 9.55$.

Boc-Gly-Ser-Lys(Z)-Val-Ile-Leu-Tyr-OH (XII)_-VII $(0.56 \mathrm{~g}, 0.64 \mathrm{mmol})$ was dissolved in cold TFA (5 ml) containing anisole $(0.5 \mathrm{ml})$ and the solution kept at $15^{\circ} \mathrm{C}$ for $45 \mathrm{~min}$. Excess of TFA was evaporated off and anhydrous $\mathrm{Et}_{2} \mathrm{O}$ was added to the residue. The precipitate $\mathrm{VII}^{\prime}$ was washed with $\mathrm{Et}_{2} \mathrm{O}$ and dried over $\mathrm{KOH} / \mathrm{P}_{2} \mathrm{O}_{5}$. $R f^{1} 0.78, R f^{2} 0.76$. Isoamyl nitrite $(0.18 \mathrm{ml}, 1.34 \mathrm{mmol})$ was added to a solution of Boc-Gly-Ser- $\mathrm{N}_{2} \mathrm{H}_{3}(0.35 \mathrm{~g}$, $1.28 \mathrm{mmol})$ in DMF $(8 \mathrm{ml})$ containing $6 \mathrm{~N} \mathrm{HCl}$ in dioxane $(0.640 \mathrm{ml}, 3.84 \mathrm{mmol})$ at $-15^{\circ} \mathrm{C}$. This mixture was stirred at $-10^{\circ} \mathrm{C}$ for $2 \mathrm{~min}$ and neutralized with an ice-cold solution of TEA $(0.538 \mathrm{ml}, 3.84 \mathrm{mmol})$ in DMF $(3 \mathrm{ml})$, and then was combined with an ice-cold solution of VII' in DMSO $(7 \mathrm{ml})$-DMF $(4 \mathrm{ml})$ containing TEA $(0.179 \mathrm{ml}, 1.28 \mathrm{mmol})$. The reaction mixture was kept for $1 \mathrm{~h}$ at $-5^{\circ} \mathrm{C}$ and for $24 \mathrm{~h}$ at $4{ }^{\circ} \mathrm{C}$ and then concentrated. The product was precipitated in the same manner as described for $\mathrm{XI}$ and reprecipitated with $\mathrm{MeOH}-\mathrm{AcOEt}-$ ether. Yield $0.48 \mathrm{~g}$ (73.8\%). mp 284-285 ${ }^{\circ} \mathrm{C}$ (dec.). $R f^{1} 0.92, R f^{2} 0.89$. [ $\left.\alpha\right]_{\mathrm{D}}^{13}-9.1^{\circ}\left(c=1\right.$, DMF). Anal. Calcd for $\mathrm{C}_{50} \mathrm{H}_{76} \mathrm{~N}_{8} \mathrm{O}_{14} \cdot 1 / 2 \mathrm{H}_{2} \mathrm{O}$ : C, 58.75; H, 7.59; N, 10.96. Found: C, 58.69; H, 7.41; N, 10.95 .

Z-pGlu-Pro-Pro-Gly-NHNH-Boc (VI)_-DCC $(1.14 \mathrm{~g}, 5.5 \mathrm{mmol})$ was added to an ice-cold solution of ZpGlu-Pro-OH ${ }^{11)}(1.80 \mathrm{~g}, 5 \mathrm{mmol})$, H-Pro-Gly-NHNHBoc ${ }^{5)}(5 \mathrm{mmol})$ [prepared from Z-Pro-Gly-NHNHBoc ${ }^{5)}$ $(2.10 \mathrm{~g})$ by catalytic hydrogenation] and $\mathrm{HOBt}(0.74 \mathrm{~g}, 5.5 \mathrm{mmol})$ in DMF ( $5 \mathrm{ml})$-tetrahydrofuran (THF) ( $25 \mathrm{ml})$. The mixture was stirred for $40 \mathrm{~h}$ at $4{ }^{\circ} \mathrm{C}$ and the resulting solid was filtered off. The filtrate was concentrated to a small volume and the residue was distributed between five portions of $n-\mathrm{BuOH}$ and ten portions of $\mathrm{H}_{2} \mathrm{O}$. The combined upper phase was concentrated to give a residue, which was passed through a column of Sephadex LH-20 $(3.2 \times 90 \mathrm{~cm})$ with $\mathrm{MeOH}-1 \% \mathrm{AcOH}(9: 1)$ as the eluent. The fractions $(8 \mathrm{~g}$ each, No. 35-37) were concentrated. The product was triturated with ether. Yield $2.09 \mathrm{~g}(66.6 \%) \mathrm{mp} 151-155^{\circ} \mathrm{C}(\mathrm{dec}.) . R f^{1} 0.57, R f^{2} 0.79 .[\alpha]_{\mathrm{D}}^{15}-99.0^{\circ}(c=1.0, \mathrm{DMF})$. Anal. Calcd for $\mathrm{C}_{30} \mathrm{H}_{40} \mathrm{~N}_{6} \mathrm{O}_{9}:$ C, 57.32; H, 6.41; N, 13.37. Found: C, 57.20; H, 6.44; N, 13.19. Amino acid ratios in an acid hydrolysate $(24 \mathrm{~h})$ : Glu 1.00 , Pro 2.00 , Gly 1.00 .

pGlu-Pro-Pro-Gly-Gly-Ser-Lys-Val-Ile-Leu-Tyr-OH (II) -XII (101 mg, $0.1 \mathrm{mmol}$ ) was partially deprotected with TFA-anisole at $15^{\circ} \mathrm{C}$ in the same manner as described for XII to give H-Gly-Ser-Lys(Z)-Val-Ile-LeuTyr-OH $\cdot$ TFA (XII'). $R f^{1} 0.55, R f^{2} 0.71$. VI $(107 \mathrm{mg}, 0.17 \mathrm{mmol})$ was treated with TFA $(5 \mathrm{ml})$ at $20^{\circ} \mathrm{C}$ for $45 \mathrm{~min}$ in the same manner as described for XII to give Z-pGlu-Pro-Pro-Gly- $\mathrm{N}_{2} \mathrm{H}_{3} \cdot$ TFA ( $\left.\mathrm{VI}^{\prime}\right) . R f^{1} 0.41, R f^{2} 0.66$. The product $\mathrm{VI}^{\prime}$ was converted to the azide in $\mathrm{DMF}(3 \mathrm{ml})$ by using $6 \mathrm{~N} \mathrm{HCl}$ in dioxane $(0.283 \mathrm{ml}, 1.7 \mathrm{mmol})$ and isoamyl nitrite $(23 \mu \mathrm{l}, 0.17 \mathrm{mmol})$ in the same manner as described for XII. The azide was coupled with XII' $\left(0.1 \mathrm{mmol}^{\prime}\right.$ in DMSO $(5 \mathrm{ml})$-DMF $(5 \mathrm{ml})$ at $4{ }^{\circ} \mathrm{C}$ for $15 \mathrm{~h}$. The product was precipitated from $20 \% \mathrm{AcOH}(80 \mathrm{ml})$, washed with $\mathrm{MeOH}(1 \mathrm{ml})$-AcOEt $(10 \mathrm{ml})$ (yield $\left.85 \mathrm{mg} ; R f^{1} 0.43, R f^{2} 0.79\right)$, and hydrogenated over $\mathrm{Pd}$ in $n$ - $\mathrm{BuOH}(5 \mathrm{ml})-\mathrm{MeOH}$ $(25 \mathrm{ml})-50 \% \mathrm{AcOH}(5 \mathrm{ml})$. The product was gel-filtered on a Sephadex G-25 column with $2 \mathrm{M} \mathrm{AcOH}$ as the eluent and 
lyophilized. Yield $65 \mathrm{mg}$. The crude material $(20 \mathrm{mg})$ was dissolved in a mixture $(2 \mathrm{ml})$ of the upper and lower phases of $n$ - BuOH-AcOEt- $\mathrm{H}_{2} \mathrm{O}(4: 1: 5)$ and subjected to DCCC which employed 200 tubes $(0.2 \times 30 \mathrm{~cm}$ each $)$ filled with the upper phase. The lower phase $(350 \mathrm{ml})$ was pumped through the tubes from top to bottom at a flow rate of $3 \mathrm{ml} / \mathrm{h}$, followed by the upper phase $(300 \mathrm{ml})$. The fractions $(3 \mathrm{~g}$ each, No. 66-120) were gel-filtered and lyophilized. Yield $17 \mathrm{mg}(48.4 \%) \cdot[\alpha]_{\mathrm{D}}^{21}-115.6^{\circ}(c=1,3 \mathrm{~m} \mathrm{AcOH})$. Anal. Calcd for $\mathrm{C}_{54} \mathrm{H}_{84} \mathrm{~N}_{12} \mathrm{O}_{10} \cdot 2 \mathrm{AcOH} \cdot 2 \mathrm{H}_{2} \mathrm{O}: \mathrm{C}, 53.69 ; \mathrm{H}, 7.46 ; \mathrm{N}$, 12.95. Found: C, 53.44; H, 6.90; N, 12.99. Amino acid ratios in an acid hydrolysate [ $24 \mathrm{~h}(48 \mathrm{~h})$ ]: Lys 0.94 (1.01), Ser 0.80 (0.85), Glu 0.97 (1.05), Pro 2.34 (2.04), Gly 2.00 (2.06), Val 0.58 (0.78), Ile 0.54 (0.77), Leu 1.01 (0.97), Tyr 0.95 (1.02), $\mathrm{NH}_{3}$ trace $(0.30)$.

Z-Val-Ile-Leu-OH (XIII)-Z Z-Val-OSu $(2.68 \mathrm{~g}, 7.7 \mathrm{mmol})$ was allowed to react with $\left.\mathrm{H}-\mathrm{Ile}-\mathrm{Leu}-\mathrm{OH} \cdot \mathrm{HCl}^{17}\right)$ $(1.97 \mathrm{~g}, 7.0 \mathrm{mmol})$ in DMF $(20 \mathrm{ml})$ containing TEA $(2.66 \mathrm{ml}, 19 \mathrm{mmol})$ at room temperature for $18 \mathrm{~h}$. The product was worked up in the same manner as described for $\mathrm{X}$ and precipitated from AcOEt-ether. The solid was reprecipitated from the same solvents. Yield $3.13 \mathrm{~g},(93.7 \%)$ mp $214-216^{\circ} \mathrm{C}(\mathrm{dec}.) . R f^{1} 0.93, R f^{2} 0.86 .[\alpha]_{\mathrm{D}}^{25}-10.0^{\circ}(c=1.0$, DMF). Anal. Calcd for $\mathrm{C}_{25} \mathrm{H}_{39} \mathrm{~N}_{3} \mathrm{O}_{6}: \mathrm{C}, 62.87 ; \mathrm{H}, 8.23 ; \mathrm{N}, 8.80$. Found: $\mathrm{C}, 63.00 ; \mathrm{H}, 8.25 ; \mathrm{N}, 8.73$.

Boc-Lys(Z)-Val-Ile-Leu-OH (VIII)-XIII ( $995 \mathrm{mg}, 2 \mathrm{mmol})$ was hydrogenated in $\mathrm{MeOH}(100 \mathrm{ml})-5 \%$ AcOH $(50 \mathrm{ml})$ in the same manner as described for XI. The product $\left(R f^{1} 0.61, R f^{2} 0.73\right)$ was reacted with BocLys $(\mathrm{Z})-\mathrm{OSu}(2.6 \mathrm{mmol})$ in DMF $(20 \mathrm{ml})-\mathrm{H}_{2} \mathrm{O}(5 \mathrm{ml})$ containing TEA $(0.433 \mathrm{ml}, 3.1 \mathrm{mmol})$ at room temperature for $20 \mathrm{~h}$. The product was worked up in the same manner as described for $\mathrm{XI}$ and reprecipitated from AcOEt-ether. Yield $1.10 \mathrm{~g}\left(78.0^{\%}\right)$. mp $164-167^{\circ} \mathrm{C} . R f^{1} 0.91, R f^{2} 0.86 .[\alpha]_{\mathrm{D}}^{25}-22.4^{\circ}(c=1.0, \mathrm{DMF})$. Anal. Calcd for $\mathrm{C}_{35} \mathrm{H}_{59} \mathrm{~N}_{5} \mathrm{O}_{9}: \mathrm{C}$, $61.26 ; \mathrm{H}, 8.42 ; \mathrm{N}, 9.92$. Found: $\mathrm{C}, 60.97 ; \mathrm{H}, 8.53 ; \mathrm{N}, 10.02$. Amino acid ratios in an acid hydrolysate [ $24 \mathrm{~h}(48 \mathrm{~h})]$ : $\mathrm{Lys}$ 1.03 (0.90), Val 0.80 (1.02), Ile 0.74 (0.97), Leu 0.97 (1.10), $\mathrm{NH}_{3} 0.33(0.26)$.

Boc-Gly-Ser-Lys(Z)-Val-Ile-Leu-OH (XIV)_-VIII $(1.19 \mathrm{~g}, 1.4 \mathrm{mmol})$ was partially deblocked with icechilled TFA $(5 \mathrm{ml})$-anisole $(0.5 \mathrm{ml})$ in the same manner as described for XII to give $\mathrm{H}-\mathrm{Lys}(\mathrm{Z})-\mathrm{Val}-\mathrm{Ile}-\mathrm{Leu}-$ $\mathrm{OH} \cdot \mathrm{TFA}\left(\mathrm{VIII}^{\prime}\right) . R f^{1} 0.75, R f^{2} 0.74$. The product was allowed to react with the azide [prepared from Boc-Gly-Ser$\left.\mathrm{N}_{2} \mathrm{H}_{3}{ }^{6}\right)(0.58 \mathrm{~g}, 2.1 \mathrm{mmol}), 6 \mathrm{~N} \mathrm{HCl}$ in dioxane $(1.12 \mathrm{ml}, 8.0 \mathrm{mmol})$ and isoamyl nitrite $\left.(0.28 \mathrm{ml}, 2.1 \mathrm{mmol})\right]$ in DMSO $(30 \mathrm{ml})$-DMF $(20 \mathrm{ml})$ at $4{ }^{\circ} \mathrm{C}$ for $18 \mathrm{~h}$. The desired product was isolated in the same manner as described for XI and reprecipitated from $\mathrm{MeOH}(40 \mathrm{ml})$-AcOEt $(80 \mathrm{ml})$. Yield $1.04 \mathrm{~g}(87.5 \%)$. mp $226-227^{\circ} \mathrm{C}\left(\mathrm{dec}\right.$.). $R f^{1} 0.85, R f^{2} 0.85$. $[\alpha]_{\mathrm{D}}^{25}-14.5^{\circ}(c=1.0, \mathrm{DMF})$. Anal. Calcd for $\mathrm{C}_{41} \mathrm{H}_{67} \mathrm{~N}_{7} \mathrm{O}_{12} \cdot \mathrm{H}_{2} \mathrm{O}: \mathrm{C}, 56.73 ; \mathrm{H}, 8.01 ; \mathrm{N}, 11.30$. Found: C, 57.00; $\mathrm{H}$, 8.14; N, 11.07. Amino acid ratios in an acid hydrolysate [24 h (48 h)]: Lys $0.93(1.08)$, Ser 0.95 (0.85), Gly 1.06 (1.07), Val 0.69 (1.01), Ile 0.80 (0.92), Leu $1.06(1.00), \mathrm{NH}_{3} 0.49(0.45)$.

pGlu-Pro-Pro-Gly-Gly-Ser-Lys-Val-Ile-Leu-OH (III)-XIV (128 mg, $0.15 \mathrm{mmol})$ was partially deblocked in the same manner as described for XII to give $\mathrm{H}-\mathrm{Gly}-\mathrm{Ser}-\mathrm{Lys}(\mathrm{Z})$-Val-Ile-Leu-OH·TFA (XIV'). $R f^{1} 0.53, R f^{2}$ 0.74 . The azide [prepared from $\mathrm{VI}^{\prime}(0.22 \mathrm{mmol}), 6 \mathrm{~N} \mathrm{HCl}$ in dioxane $(178 \mu \mathrm{l}, 1.10 \mathrm{mmol})$ and isoamyl nitrite $(30 \mu \mathrm{l}$, $0.22 \mathrm{mmol})$ in DMF $(4 \mathrm{ml})$ ] was allowed to react with $\mathrm{XIV}^{\prime}$ in DMSO $(4 \mathrm{ml})$-DMF $(6 \mathrm{ml})$ containing TEA $(55 \mu \mathrm{l}$, $0.39 \mathrm{mmol}$ ) at $4{ }^{\circ} \mathrm{C}$ for $20 \mathrm{~h}$, then the mixture was concentrated. The resulting residue was triturated with $5 \% \mathrm{AcOH}$, reprecipitated from $\mathrm{MeOH}-\mathrm{AcOEt}\left(115 \mathrm{mg}, R f^{1} 0.47, R f^{2} 0.77\right.$ as main spot), and hydrogenated in $n$ - $\mathrm{BuOH}(15 \mathrm{ml})-$ $\mathrm{MeOH}(15 \mathrm{ml})-10 \% \mathrm{AcOH}(15 \mathrm{ml})$. The product in $2 \mathrm{M} \mathrm{AcOH}$ was applied to a column $(3.0 \times 103 \mathrm{~cm})$ of Sephadex G25 (fine). The fractions $\left(8 \mathrm{~g}\right.$ each, No. 51-59) were lyophilized. Yield $41 \mathrm{mg}(45.0 \%) . R f^{1} 0.11, R f^{2} 0.48 .[\alpha]_{\mathrm{D}}^{25}$ $-117.6^{\circ}(c=1.0,3 \mathrm{M} \mathrm{AcOH})$. Anal. Calcd for $\mathrm{C}_{45} \mathrm{H}_{75} \mathrm{~N}_{11} \mathrm{O}_{13} \cdot \mathrm{AcOH}: \mathrm{C}, 54.37 ; \mathrm{H}, 7.67 ; \mathrm{N}, 14.84$. Found: $\mathrm{C}, 54.35 ; \mathrm{H}$, 7.40; N, 14.59. Amino acid ratios in an acid hydrolysate [24 h (48 h)]: Lys $1.01(1.08)$, Ser $0.91(0.82)$, Glu 1.05 (1.05), Pro 2.02 (2.02), Gly 2.06 (2.07), Val 0.79 (0.98), Ile $0.74(0.90)$, Leu $0.95(0.95), \mathrm{NH}_{3} 0.54(0.65)$.

Z-Ile-Leu-Phe-OH (XV)-Z-Ile-OSu $(6.12 \mathrm{~g}, 16.9 \mathrm{mmol})$ was allowed to react at room temperature for $20 \mathrm{~h}$ with $\mathrm{H}$-Leu-Phe-OH $\left.{ }^{18}\right)(3.62 \mathrm{~g}, 13 \mathrm{mmol})$ in DMF $(25 \mathrm{ml})-\mathrm{H}_{2} \mathrm{O}(10 \mathrm{ml})$ containing TEA $(3.09 \mathrm{ml}, 22.1 \mathrm{mmol})$. The mixture was treated in the same manner as described for $\mathrm{X}$. The residue was triturated with ether-petr. ether. The solid was reprecipitated from AcOEt-ether. Yield $5.34 \mathrm{~g}(76.8 \%) \cdot \mathrm{mp} 156-158^{\circ} \mathrm{C} . R f^{1} 0.88, R f^{2} 0.78 .[\alpha]_{\mathrm{D}}^{15}-5.7^{\circ}$ $\left(c=1.0\right.$, DMF). Anal. Calcd for $\mathrm{C}_{29} \mathrm{H}_{39} \mathrm{~N}_{3} \mathrm{O}_{6} \cdot 1 / 2 \mathrm{H}_{2} \mathrm{O}: \mathrm{C}, 65.15 ; \mathrm{H}, 7.54 ; \mathrm{N}, 7.86$. Found: $\mathrm{C}, 65.15 ; \mathrm{H}, 7.50 ; \mathrm{N}, 7.73$.

Z-Val-Ile-Leu-Phe-OH (XVI)_- XV $(3.48 \mathrm{~g}, 6.5 \mathrm{mmol})$ was hydrogenated in $\mathrm{MeOH}(40 \mathrm{ml})-50 \% \mathrm{AcOH}$ $(20 \mathrm{ml})$ in the same manner as described for XI. The product $\left(R f^{1} 0.66, R f^{2} 0.73\right)$ was precipitated from EtOH and allowed to react with $\mathrm{Z}$-Val-OSu $(2.72 \mathrm{~g}, 7.8 \mathrm{mmol})$ at room temperature for $20 \mathrm{~h}$ in $\mathrm{H}_{2} \mathrm{O}(5 \mathrm{ml})-\mathrm{DMSO}(5 \mathrm{ml})-\mathrm{DMF}$ $(40 \mathrm{ml})$ containing TEA $(1.54 \mathrm{ml}, 11 \mathrm{mmol})$. XVI was isolated in the same manner as described for XI and reprecipitated from $\mathrm{MeOH}$-ether. Yield $3.17 \mathrm{~g}(76.9 \%)$. mp $227-228^{\circ} \mathrm{C} . R f^{1} 0.86, R f^{2} 0.78 .[\alpha]_{\mathrm{D}}^{15}-9.5^{\circ}(c=1.0$, DMF). Anal. Calcd for $\mathrm{C}_{34} \mathrm{H}_{48} \mathrm{~N}_{4} \mathrm{O}_{7} \cdot 1 / 2 \mathrm{H}_{2} \mathrm{O}: \mathrm{C}, 64.43 ; \mathrm{H}, 7.79 ; \mathrm{N}, 8.84$. Found: C, 64.77; H, 7.89; N, 8.94.

Boc-Lys(Z)-Val-Ile-Leu-Phe-OH (IX) - XVI (1.90 g, $3 \mathrm{mmol})$ was hydrogenated in $\mathrm{MeOH}(40 \mathrm{ml})-n$-BuOH $(20 \mathrm{ml})-50 \% \mathrm{AcOH}(20 \mathrm{ml})$ in the same manner as described for XI. The product $\left(R f^{1} 0.66, R f^{2} 0.78\right)$ in DMSO $(20 \mathrm{ml})$-DMF $(20 \mathrm{ml})$ containing TEA $(0.56 \mathrm{ml}, 6 \mathrm{mmol})$ was coupled with Boc-Lys $(\mathrm{Z})-\mathrm{OSu}(6 \mathrm{mmol})$ at room temperature. After $18 \mathrm{~h}$, the mixture was treated in the same manner as described for XI and the product was reprecipitated from $\mathrm{MeOH}$-ether. Yield $2.03 \mathrm{~g}\left(79.4 \%\right.$ ). $\mathrm{mp} 295-297^{\circ} \mathrm{C}$ (dec.). $R f^{1} 0.89, R f^{2} 0.74 .[\alpha]_{\mathrm{D}}^{15}-15.7^{\circ}$ $\left(c=1.0\right.$, DMF). Anal. Calcd for $\mathrm{C}_{45} \mathrm{H}_{68} \mathrm{~N}_{6} \mathrm{O}_{10}: \mathrm{C}, 63.36 ; \mathrm{H}, 8.03 ; \mathrm{N}, 9.85$. Found: C, 63.00; H, 8.06; N, 9.88.

Boc-Gly-Ser-Lys(Z)-Val-Ile-Leu-Phe-OH (XVII)_- IX $(1.11 \mathrm{~g}, 1.3 \mathrm{mmol})$ was partially deblocked with icechilled TFA $(10 \mathrm{ml})$-anisole $(1.3 \mathrm{ml})$ in the same manner as described for XII to give $\mathrm{H}-\mathrm{Lys}(\mathrm{Z})-\mathrm{Val}-\mathrm{Ile}-\mathrm{Leu}-\mathrm{Phe}$ $\mathrm{OH} \cdot \mathrm{TFA}\left(\mathrm{IX}^{\prime}\right) . R f^{1} 0.75, R f^{2} 0.73$. IX $\mathrm{X}^{\prime}$ in DMSO $(30 \mathrm{ml})$-DMF $(15 \mathrm{ml})$ was allowed to react with azide [prepared 
from Boc-Gly-Ser- $\mathrm{N}_{2} \mathrm{H}_{3}(0.72 \mathrm{~g}, 2.6 \mathrm{mmol}), 6 \mathrm{~N} \mathrm{HCl}$ in dioxane $(1.73 \mathrm{ml}, 10.4 \mathrm{mmol})$ and isoamyl nitrite $(0.35 \mathrm{ml}$, $2.6 \mathrm{mmol}$ )] at $4{ }^{\circ} \mathrm{C}$ for $20 \mathrm{~h}$. The mixture was treated in the same manner as described for XI and the product was washed with $\mathrm{MeOH}$. Yield $1.00 \mathrm{~g}\left(76.8^{\circ}\right)$. mp $275-279^{\circ} \mathrm{C}\left(\mathrm{dec}\right.$.). $R f^{1} 0.86, R f^{2} 0.80 .[\alpha]_{\mathrm{D}}^{15}-13.9^{\circ}(c=1.0, \mathrm{DMF})$. Anal. Calcd for $\mathrm{C}_{50} \mathrm{H}_{76} \mathrm{~N}_{8} \mathrm{O}_{13}: \mathrm{C}, 60.22 ; \mathrm{H}, 7.68 ; \mathrm{N}, 11.24$. Found: $\mathrm{C}, 59.77 ; \mathrm{H}, 7.70 ; \mathrm{N}, 11.35$. Amino acid ratios in an acid hydrolysate [24 h (48 h)]: Ser $0.99(0.82)$, Gly $1.06(0.98)$. Val $0.61(0.73)$, Ile $0.63(0.78)$, Leu $1.03(0.97)$, Phe 0.98 (0.91), Lys 0.93 (1.15), $\mathrm{NH}_{3} 0.25(0.43)$.

H-Arg-Pro-Pro-Gly-Gly-Ser-Lys-Val-Ile-Leu-Phe-OH (IV)-Z-Arg $\left(\mathrm{NO}_{2}\right)$-Pro-Pro-Gly-NHNHBoc ${ }^{5}$ $(144 \mathrm{mg}, 0.2 \mathrm{mmol})$ was treated with TFA $(3 \mathrm{ml})$ in the usual manner. The product was converted to the corresponding azide with $6 \mathrm{~N} \mathrm{HCl}$ in dioxane $(0.167 \mathrm{ml}, 1 \mathrm{mmol})$ and isoamyl nitrite $(0.027 \mathrm{ml}, 0.2 \mathrm{mmol})$ in DMF ( $4 \mathrm{ml}$ ) and coupled at $4{ }^{\circ} \mathrm{C}$ for $22 \mathrm{~h}$ with $\mathrm{H}-\mathrm{Gly}-\mathrm{Ser}-\mathrm{Lys}(\mathrm{Z})-\mathrm{Val}-\mathrm{Ile}-\mathrm{Leu}-\mathrm{Phe}-\mathrm{OH} \cdot \mathrm{TFA}(\mathrm{XVII})$, which was derived from XVII ( $100 \mathrm{mg}, 0.1 \mathrm{mmol})$ in the same manner as described for XII. The mixture was concentrated. The residue was precipitated from $20 \% \mathrm{AcOH}$ and reprecipitated from $\mathrm{MeOH}-\mathrm{AcOEt}$. Yield $106 \mathrm{mg}, R f^{1} 0.55, R f^{2} 0.73$. The solid was hydrogenated over $\mathrm{Pd}$ and purified by DCCC using a solvent system of $n$ - $\mathrm{BuOH}-\mathrm{AcOH}-\mathrm{H}_{2} \mathrm{O}(4: 1: 5)$ in the same manner as described for II. The lower phase fractions ( $2 \mathrm{~g}$ each, No. 11-31) were gel-filtered on a Sephadex G-25 column. Yield $57 \mathrm{mg}\left(49.0^{\circ}\right) \cdot[\alpha]_{\mathrm{D}}^{13}-99.3^{\circ}(c=1,1 \mathrm{~m} \mathrm{AcOH})$. Anal. Calcd for $\mathrm{C}_{55} \mathrm{H}_{99} \mathrm{~N}_{15} \mathrm{O}_{13} \cdot 3 \mathrm{AcOH} \cdot 3 \mathrm{H} \mathrm{H}_{2} \mathrm{O}$ : C, 51.80; H, 7.82; N, 14.96. Found: C, 51.80; H, 7.41; N, 15.16. Amino acid ratios in an acid hydrolysate [24 h $(48 \mathrm{~h})]$ : Ser 0.69 (0.75), Pro 1.85 (1.92), Gly 1.86 (2.19), Val 0.67 (0.96), Ile 0.64 (0.95), Leu 0.86 (1.06), Phe 0.89 (1.04), Lys 1.12 (0.98), Arg 1.14 (1.13), $\mathrm{NH}_{3} 0.34$ (0.58).

Boc-Phe-Ser-Lys(Z)-Val-Ile-Leu-Phe-OH (XVIII)-The azide [prepared from Boc-Phe-Ser- $\mathrm{N}_{2} \mathrm{H}_{3}{ }^{7)}$ $(257 \mathrm{mg}, 0.70 \mathrm{mmol}), 6 \mathrm{~N} \mathrm{HCl}$ in dioxane $(0.55 \mathrm{ml}, 3.5 \mathrm{mmol})$, and isoamyl nitrite $(0.094 \mathrm{ml}, 0.70 \mathrm{mmol})$ in DMF $(30 \mathrm{ml})$ in the usual manner] was coupled with $\mathrm{IX}^{\prime}$ [prepared from IX $(0.299 \mathrm{~g}, 0.35 \mathrm{mmol})$ in the same manner as described for XII] at $4{ }^{\circ} \mathrm{C}$ for $20 \mathrm{~h}$. The product was isolated in the same manner as described for XI and reprecipitated from DMF-MeOH. Yield $0.32 \mathrm{~g}(83.0 \%) \cdot R f^{1} 0.85, R f^{2} 0.78 . \mathrm{mp} 292-294 \mathrm{C}\left(\mathrm{dec}\right.$ ). $[\alpha]_{\mathrm{D}}^{15}-11.2$ $\left(c=1\right.$, DMF). Anal. Calcd for $\mathrm{C}_{57} \mathrm{H}_{82} \mathrm{~N}_{8} \mathrm{O}_{13}: \mathrm{C}, 62.96 ; \mathrm{H}, 7.60 ; \mathrm{N}, 10.31$. Found: $\mathrm{C}, 62.63 ; \mathrm{H}, 7.70 ; \mathrm{N}, 10.41$. Amino acid ratios in an acid hydrolysate $[24 \mathrm{~h}(48 \mathrm{~h})]$ : Ser $0.92(0.80)$, Val $0.52(0.74)$, Ile $0.57(0.75)$, Leu $0.97(1.02)$, Phe 1.94 (1.88), Lys 1.09 (1.08), $\mathrm{NH}_{3} 0.20$ (0.17).

pGlu-Pro-Pro-Gly-Phe-Ser-Lys-Val-Ile-Leu-Phe-OH (V)-XVIII $(218 \mathrm{mg}, 0.2 \mathrm{mmol})$ was treated with TFA $(5 \mathrm{ml})$-anisole $(0.5 \mathrm{ml})$ in the usual manner to give $\mathrm{H}-\mathrm{Phe}-\mathrm{Ser}-\mathrm{Lys}(\mathrm{Z})$-Val-Ile-Leu-Phe-OH$\cdot \mathrm{TFA}\left(\mathrm{XVIII}^{\prime}\right)$. $R f^{1} 0.72, R f^{2} 0.70$. The azide [prepared from $\mathrm{VI}^{\prime}(0.34 \mathrm{mmol})$ as described for II] was coupled with XVIII' in DMSO $(20 \mathrm{ml})-\mathrm{DMF}(20 \mathrm{ml})$ at $4{ }^{\circ} \mathrm{C}$ for $48 \mathrm{~h}$. The product was isolated in the same manner as described for XI, washed with $\mathrm{MeOH}$-AcOEt [yield $190 \mathrm{mg} ; R f^{1} 0.72, R f^{2} 0.67$ (main spot)], hydrogenated over $\mathrm{Pd}$ in $n$ - $\mathrm{BuOH}-\mathrm{MeOH}-50 \% \mathrm{AcOH}$ $(20 \mathrm{ml}: 20 \mathrm{ml}: 10 \mathrm{ml})$ and gel-filtered on Sephadex G-25 to give crude V (41 mg), which was subjected to DCCC using $n$ - $\mathrm{BuOH}-\mathrm{AcOH}-\mathrm{H}_{2} \mathrm{O}(4: 1: 5)$ in the same manner as described for II. After elution with the lower phase $(300 \mathrm{ml})$, fractions (4 g each, No. 112-121) of the upper phase eluate were gel-filtered on Sephadex G-25. Yield $30 \mathrm{mg}(15.0 \%)$. $[\alpha]_{D}^{15}-113.0^{\circ}(c=0.5,3 \mathrm{M} \mathrm{AcOH})$. Anal. Calcd for $\mathrm{C}_{61} \mathrm{H}_{90} \mathrm{~N}_{12} \mathrm{O}_{14} \cdot \mathrm{AcOH} \cdot 2 \mathrm{H}_{2} \mathrm{O}: \mathrm{C}, 57.70 ; \mathrm{H}, 7.53 ; \mathrm{N}, 12.82$. Found: C, 57.47; H, 7.26; N, 13.03. Amino acid ratios in an acid hydrolysate [24 h (48 h)]: Ser 1.17 (1.08), Glu 0.89 (0.97), Pro 1.95 (1.99), Gly 0.93 (1.06), Val 0.56 (0.87), Ile $0.59(0.85)$, Leu $0.98(1.03)$, Phe 2.02 (1.95), Lys $0.85(1.01), \mathrm{NH}_{3} 0.15$ (0.27).

pGlu-Pro-Pro-Gly-Gly-Ser-Lys-Val-Ile-Leu-Phe-OH (I)_-The azide [prepared from VI' (1.0 mmol)] was coupled with XVII' $(0.5 \mathrm{mmol})$ in DMSO $(15 \mathrm{ml})-\mathrm{DMF}(10 \mathrm{ml})$ at $4{ }^{\circ} \mathrm{C}$ for $20 \mathrm{~h}$. The product was isolated in the same manner as described for XI, and washed with $\mathrm{MeOH}-\mathrm{AcOEt}$. Yield $632 \mathrm{mg}(90.7 \%) . R f^{1} 0.48, R f^{2} 0.78$ (main spot). The solid $(500 \mathrm{mg})$ was hydrogenated in $n-\mathrm{BuOH}-\mathrm{MeOH}-10 \% \mathrm{AcOH}(1: 1: 1)(60 \mathrm{ml})$ over Pd and lyophilized from $1 \mathrm{M} \mathrm{AcOH}$. Yield $401 \mathrm{mg}$. Crude I ( $100 \mathrm{mg})$ was subjected to DCCC using a solvent system of $n-\mathrm{BuOH}-\mathrm{AcOH}-\mathrm{H}_{2} \mathrm{O}$ $(4: 1: 5)$ in the same manner as described for II. The fractions $(4 \mathrm{~g}$ each, No. $92-121)$ were concentrated to a small volume and passed through a column $(3.2 \times 90 \mathrm{~cm})$ of Sephadex G-25 (fine) using $2 \mathrm{M} \mathrm{AcOH}$ as the eluent. The fractions ( $8 \mathrm{~g}$ each, No. 45-51) were lyophilized. Yield $68 \mathrm{mg}$. The product was then subjected to DCCC again using a solvent system of $n$ - $\mathrm{BuOH}$-pyridine- $0.1 \% \mathrm{AcOH}(5: 3: 11)$. The lower phase $(300 \mathrm{ml})$ was used as the mobile phase. The fractions ( $4 \mathrm{~g}$ each, No. 65-85) were concentrated, lyophilized, and passed through a Sephadex G-25 column. The product was lyophilized from $2 \mathrm{M} \mathrm{AcOH}$. Yield $56 \mathrm{mg}(36.0 \%) \cdot[\alpha]_{\mathrm{D}}^{15}-127.5^{\circ}(c=1,3 \mathrm{M} \mathrm{AcOH})$. Anal. Calcd for $\mathrm{C}_{54} \mathrm{H}_{8} \mathrm{~N}_{12} \mathrm{O}_{14} \cdot \mathrm{AcOH} \cdot 3 \mathrm{H}_{2} \mathrm{O}: \mathrm{C}, 54.27 ; \mathrm{H}, 7.64 ; \mathrm{N}, 13.56$. Found: C, 54.52; H, 7.30; N, 13.95. Amino acid ratios in an acid hydrolysate [24 h (48 h)]: Ser $0.93(0.81)$, Glu $1.05(1.05)$, Pro $1.98(1.94)$, Gly $2.06(1.95)$, Val $0.61(0.82)$, Ile 0.58 (0.75), Leu 1.02 (0.99), Phe 0.99 (0.98), Lys 1.02 (1.05), $\mathrm{NH}_{3} 0.14(0.38)$.

Immunochemical Experiments

Preparation of Conjugate_-A $2 \%$ aqueous solution of glutaraldehyde $(1 \mathrm{ml})$ was added dropwise to an ice-cold solution of $\mathrm{HA}(7.5 \mathrm{mg})$ and crude protein extract of Ascaris suilla $(15 \mathrm{mg})$ in $\mathrm{H}_{2} \mathrm{O}(7.5 \mathrm{ml})$ during $30 \mathrm{~min}$. The mixture was stirred overnight at $4{ }^{\circ} \mathrm{C}$ and taken into dialysis tubing (Spectrapor, MW cut-off 1000). The dialysis was continued at $4{ }^{\circ} \mathrm{C}$ for $20 \mathrm{~h}$ with two changes of $\mathrm{H}_{2} \mathrm{O}(1 \mathrm{l}$ each) and the dialysate was lyophilized. Yield $13 \mathrm{mg}$.

Immunization - The conjugate $(3 \mathrm{mg})$ was dissolved in saline $(1.5 \mathrm{ml})$ and the solution was emulsified with complete Freund's adjuvant ( $1.5 \mathrm{ml}$, Calbiochem-Behring) in a Sorval Omni-Mixer at $50000 \mathrm{rpm}$. The emulsion was injected subcutaneously at multiple sites on three mixed-bred male rabbits. The rabbits were boosted three times at 
biweekly intervals and monthly thereafter using a half amount of the conjugate. Blood was taken at $10 \mathrm{~d}$ after the injection. All rabbits produced antibodies after the 5 th injection.

Labelled Antigen Preparation-A solution of II $(11 \mu \mathrm{g}, 9.2 \mathrm{nmol})$ in $\mathrm{H}_{2} \mathrm{O}(22 \mu \mathrm{l})$ was added to a solution of ${ }^{125} \mathrm{INa}(250 \mu \mathrm{Ci}, 0.115 \mathrm{nmol})$ in $0.25 \mathrm{M}$ phosphate buffer $(50 \mu \mathrm{l}, \mathrm{pH} 7.40)$ in a glass tube, which had been filmed with 1,3,4,6-tetrachloro-3 $\alpha, 6 \alpha$-diphenyl-glycouril $\left(0.99 \mu \mathrm{g}, 2.3 \mathrm{nmol}\right.$, Iodogen, Pierce) at the bottom. ${ }^{16)}$ The mixture was stirred on a test tube mixer and allowed to react for $5 \mathrm{~min}$. The product was purified on a column $(3.9 \times 30 \mathrm{~mm})$ of Chemcosorb 7-ODS-H with a linear gradient of acetonitrile from $10 \%$ to $30 \%$ over a period of $15 \mathrm{~min}$ in $20 \mathrm{~mm}$ phosphate buffer ( $\mathrm{pH} 3.0$ ), at flow rate of $0.8 \mathrm{ml} / \mathrm{min}$. Fractions of the highest radioactivity (retention time: $13.5 \mathrm{~min}$ ) were used as the labelled antigen in HA-RIA.

Radioimmunoassay (RIA) - - The standard diluent (SD) used was $10 \mathrm{~mm}$ phosphate buffer ( $\mathrm{pH} 7.40$ ), containing $0.5 \%$ bovine serum albumin (BSA), $0.025 \mathrm{~m}$ ethylenediaminetetraacetic acid (EDTA) and $0.15 \mathrm{M} \mathrm{NaCl}$. The mixture in each assay tube consisted of SD $(0.5 \mathrm{ml})$, peptide or tissue extract $(0.1 \mathrm{ml})$, diluted antiserum $(0.1 \mathrm{ml})$ and labelled antigen $(0.1 \mathrm{ml}$, approximately $10000 \mathrm{cpm})$. The mixture was incubated at $4{ }^{\circ} \mathrm{C}$ overnight, and $0.5 \%$ normal rabbit serum $(0.1 \mathrm{ml}), 10 \%$ goat anti-rabbit $\gamma$-globulin serum $(0.1 \mathrm{ml})$ and $30 \%$ polyethyleneglycol ${ }^{19)}$ in BSA free SD were added. After an additional incubation for $1 \mathrm{~h}$ at $4{ }^{\circ} \mathrm{C}$, the mixture was centrifuged at $3000 \mathrm{rpm}$ at $4{ }^{\circ} \mathrm{C}$. The supernatant was removed and the radioactivity in the tube was counted.

Tissue Extraction - Rat whole intestine and whole brain were diced, immersed in a small amount of $2 \mathrm{M} \mathrm{AcOH}$ and then plunged into a boiling water bath for $5 \mathrm{~min}$. The mixture was cooled and homogenized in a ten fold excess of ice-cold $2 \mathrm{~m} \mathrm{AcOH}$. A supernatant was obtained by centrifugation at $30000 \times \boldsymbol{g}$ for $20 \mathrm{~min}$, and the precipitate was reextracted in the same manner. The combined supernatant was washed with three portions of $\mathrm{CHCl}_{3}$ and lyophilized.

Acknowledgements The authors wish to express their gratitude to Professor N. Yanaihara, Shizuoka College of Pharmacy, for his valuable advice during the preparation of this manuscript. The authors are also grateful to Drs. H.C. Schaller and H. Bodenmüller for the bioassay and radioimmunoassay of our synthetic peptides.

\section{References}

1) H. C. Schaller and H. Bodenmüller, Proc. Natl. Acad. Sci. U.S.A., 78, 7000 (1981).

2) H. C. Schaller and H. Bodenmüller, Colloq. Ges. Biol. Chem., 33, 247 (1982); idem, Biol. Chem. Hoppe-Seyler, 366, 1003 (1985).

3) H. Bodenmüller and H. C. Schaller, Nature (London), 293, 579 (1981).

4) G. E. Feurle, H. Bodenmüller, and I. Baća, Neurosci. Lett., 38, 287 (1983).

5) R. A. Boissonnas, St. Guttmann, and P.-A. Jaquenoud, Helv. Chim. Acta, 43, 1349 (1960).

6) K. Akaji, N. Fujii, H. Yajima, M. Moriga, A. Takagi, K. Mizuta, M. Noguchi, and T. J. McDonald, Int. J. Pept. Protein Res., 20, 276 (1982).

7) C. Hashimoto, M. Tamaki, H. Uchida, S. Nozaki, S. Sofuku, and I. Muramatsu, "Peptide Chemistry 1978," ed. by N. Izumiya, Protein Research Foundation, Osaka, 1979, p. 115.

8) A. R. Mitchell, S. B. H. Kent, I. C. Chu, and R. B. Merrifield, Anal. Chem., 50, 637 (1978).

9) B. W. Erickson and R. B. Merrifield, J. Am. Chem. Soc., 95, 3757 (1973).

10) J. Honzl and J. Rudinger, Collect. Czech. Chem. Commun., 26, 2333 (1961).

11) V. Erspamer and A. Anastasi, Experientia, 18, 58 (1962).

12) W. König and R. Geiger, Chem. Ber., 103, 788 (1970).

13) H. Akaji, T. Hayashi, T. Nakayama, T. Nakajima, T. X. Watanabe, and H. Sokabe, Chem. Pharm. Bull., 30, 2498 (1982).

14) M. Roberger, E. Escher, H. C. Schaller, and H. Bodenmüller, FEBS Lett., 173, 307 (1984); H. Bodenmüller and B. Zachmann, ibid., 159, 237 (1983).

15) K. Nokihara, C. Yanaihara, K. Iguchi, S. Fukata, M. Tanaka, T. Mochizuki, K. Tatemoto, J. M. Lundberg, V. Mutt, and N. Yanaihara, J. Am. Chem. Soc., 106, 7909 (1984).

16) P. R. Salacinski, J. Hope, C. McLean, V. Clement-Jones, J. Sykes, J. Price, and P. J. Lowry, J. Endocrinol, 81, 131 (1979).

17) Su-S. Wang and I. D. Kulesha, J. Org. Chem., 40, 1227 (1975).

18) R. Hirschmann, R. G. Strachan, H. Schwam, E. F. Schoenewaldt, H. Joshua, B. Barkemeyer, D. F. Veber, W. J. Paleveda, Jr., T. A. Jacob, T. E. Beesley, and R. G. Denkewalter, J. Org. Chem., 32, 3415 (1967).

19) M. R. Pandian, A. Horvat, and S. I. Said, "Vasoactive Intestinal Peptide," ed. by S. I. Said, Raven, New York, 1982, p. 35. 